\title{
Vaktaalrubriek
}

\section{Afrikaanse tandheelkundige vaktaal}

\author{
P.J. Germishuys \\ Departement Periodonsie en Mondgeneeskunde, Universiteit van Pretoria, Pretoria, 0002
}

Ten tye van die stigting van die Fakulteit Tandheelkunde aan die Universiteit van Pretoria as die eerste fakulteit met Afrikaans as voertaal, was daar nog weinig taalkundige riglyne beskikbaar vir die ontwikkeling van tandheelkundige vaktaal. Die eerste dekaan, prof. Phil Joubert, het sy professionele kwalifikasie aan die Universiteit van Utrecht in Nederland verwerf. Dit is dan ook logies dat deur sy invloed die Afrikaanse tandheelkundige vaktaal gedeeltelik aan Nederlands ontleen is.

Op die gebied van geneeskunde het daar reeds twee Afrikaanse woordeboeke verskyn - een in 1972 en die ander in 1979. Tot dusver bestaan daar geen woordeboek of woordelys vir tandheelkunde nie. In die Geneeskundewoordeboek van Snyman word vermeld dat 'n lys voorgelê is deur lede van die Universiteit van Pretoria se Fakulteit Tandheelkunde. Uit hierdie lys is nagenoeg 250 terme in die publikasie opgeneem. Daar het wel twee handboeke, een oor Mondbiologie en die ander oor Kaak-, Gesig- en Mondchirurgie in Afrikaans verskyn. Aangesien beide die handboeke handel oor onderwerpe wat nou aansluit by geneeskunde, kon in 'n mate gebruik gemaak word van bestaande Afrikaanse geneeskundige woordeboeke. Waar die woordeboeke nie die nodige verskaf het nie, moes nuwe Afrikaanse woorde geskep word. Aangesien tandheelkunde 'n snelgroeiende wetenkskap is, is daar feitlik maandeliks ' $n$ behoefte aan nuwe Afrikaanse woorde en terme.

Wanneer daar gekyk word na die vertalings wat in H.W. Snyman se Geneeskundewoordeboek ${ }^{2}$ (SGW) verskyn, vind ons dat die verafrikaanste vorm van die Engels of die klassieke (Grieks of Latyn) dikwels die vorm is wat gebruik word eerder as die Germaanse of volkseie. Hieronder volg enkele voorbeelde. Die Engelse woord word verskaf met die verafrikaanste vorm en in sommige gevalle ook 'n volkseie of Germaanse woord. Die Engelse woord en die Afrikaanse vorm wat die meeste gebruik word, verskyn in vetdruk.

abutment:

clasp:

comminuted fracture: stuttand - laasgenoemde het in ' $n$ mate in onbruik verval en word vervang met ankertand.

knyper, knip, klem, tandstekelhaak - nie enige van die vorme word gebruik nie. Dit word vervang met klammer.

gruisfraktuur, vergruisde fraktuur, gruisbreuk,

brokkelbreuk - nie een hiervan word baie dikwels gebruik nie. Dit word vervang met brokkelfraktuur. In hierdie verband moet vermeld word dat die term fraktuur baie meer gebruik word as breuk.

correction:

cusp:

cuspal interference:

dental calculus:

dentofacial:

denture:

dislocation:

exposure (van tandpulpa): blootstelling, ontbloting - nie

facing:

flange:

gold foil restoration:

jacket crown:

malocclusion:

pontic:

post with coping or thimble: een van die twee word algemeen gebruik nie en is vervang deur blootlegging.

korreksie, verbetering, regstelling.

kusp, tandknobbel, knobbel. Laasgenoemde en kusp word moontlik eweveel gebruik.

kom nie voor in SGW nie - die term knobbelstruikeling is geskep.

\section{tandsteen.}

dentofasiaal, tand-gesig

dentuur, gebit, tandestel, kunsgebit.

dislokasie, verskuiwing, ontwrigting.

tandkroonteenstuk - word selde gebruik en is vervang deur gesigstuk.

flens.

bladgoudherstelling.

dopkroon.

wanokklusie, wansluiting.

foptand, brugtand.

stif met kappie of vingerhoed. 
radiograph:

resin:

rubberdam:

screening:

socket:

tissue conditioner:

topical:

unerupted tooth: straalfoto - hierdie woord word baie selde in tandheelkunde gebruik en is vervang deur röntgenfoto (roentgenfoto).

wortelreste.

resien, hars. Eersgenoemde word selde gebruik.

gomlastieklaken, rubberlaken, kofferdam - eersgenoemde twee word selde gebruik.

siftingsondersoek - SGW gee die term siftingstoets vir die Engelse "screening test".

kas, holte, potjie - die term tandkas word algemeen gebruik.

weefselopknapper is die gebruiklike woord.

topies, gelokaliseerd, plaaslik. Nie een van die woorde het ingang gevind nie en oppervlakaanwending word gebruik vir "topical application" en oppervlaksverdowing vir "topical anaesthesia".

sluimertand, onverskene tand - die terme word selde gebruik en word vervang deur beklemde tand wat nie heeltemal korrek is nie aangesien laasgenoemde tand glad nie kan erupteer nie, in teenstelling met sluimertand en onverskene tand wat moontlik nog kan erupteer.

Daar is ' $n$ neiging om in die geval van apparate, operatiewe prosedures en siektetoestande die verafrikaanste vorm van die Engelse woord te gebruik. Hier volg enkele voorbeelde. Die Engelse woord en die algemene gebruiksvorm verskyn in vetdruk:

bandpusher:

bandstoter.

curette:

kuret, uitskraper, skraap-

lepel.

excavator:

uitholtoestel, ekskavator.

juvenile periodontitis: jeugdige, juveniele perio- dontitis; dit wil voorkom of die byvoeglike naamwoord “jeugdig" nie die mas kan opkom nie. "Juveniel" verskyn nie in SGW nie maar wel in Brink se Woordeboek van Afrikaanse Geneeskundeterme. ${ }^{\prime}$

laser: laser.

postoperative:

postoperatief, na-operatief.

retractor:

oopsperder, wondhaak, retraktor.

scaler:

skaleerder.

sticky wax:

kleefwas.

template:

templaat, sjabloon, (giet)vorm, gidsplaat.

trephine:

trefien, weefselboor, beenboor, buisboor.

trocar:

trokar, tapnaald,driehoeknaald.

Die volgende is enkele woorde en terme wat nie as sulks in woordeboeke aangetref word nie:

headgear: koptuig.

interceptive orthodontics: onderskeppende ortodonsie.

overclosure:

diepbyt, toebyt.

retainer (Hawley):

SGW vertaal "retainer" as 'n tandanker. Hier gaan dit oor 'n apparaat wat die tande, wat met ortodontiese prosedures reg belyn is, vir ' $n$ tyd lank in posisie hou en daarom word die term retensieapparaat (Hawley) gebruik.

space maintainer:

spasiebehouer; die apparaat moet verhoed dat sekere spasies in die gemengde gebit (melk en permanente) verlore gaan.

vertrek; dit het betrekking op materiale, bv. afdrukmateriaal wat na manipulasie dimensionele veranderings ondergaan en daartoe kan lei dat die pas van o.a. gietstukke nadelig beïnvloed kan word. 


\section{yield strength:}

reksterkte van materiale wat vir herstellings aan tande gebruik word.

Met die raadpleeg van die woordeboeke het dit ook geblyk dat daar nog baie woorde en terme is wat nog nie "goed" vertaal is nie of waarvoor daar nog nie neologismes bestaan nie. Hier word gedink aan die woord "postdam" Geslagte Afrikaanssprekende tandartse en tandtegnici gebruik deur die jare hierdie Engelse term. Dit dui op die aanbring van 'n dun randjie op die draende oppervlakte van die boonste kunsgebit se rand wat rus op die aansluiting tussen die harde en sagte verhemelte. Dit bevorder'n goeie pas van die boonste kunsgebit en verhoed dat voedselreste onder die kunsgebit inkom.

'n Ander term wat ook hardnekkig weier om "goed" vertaal te word is: "Hay rake appliance" wat 'n ortodontiese apparaat is. Die doel van die apparaat is om verkeerde tongstootgewoontes af te leer. Daar word gepraat van "tongspore", maar dit lyk nie of dit byval vind nie.

Die uitspraak van sekere terme volg nie altyd dié wat deur die woordeboeke voorgestel word nie,bv. gutta-percha: droë gesuiwerde lateks (van bome afkomstig) wat in tandheelkunde gebruik word om wortelkanale mee te vul.
Die uitspraak kan volgens The Concise Oxford Dictionary wees "gutta-perka" of "gutta-persja". Laasgenoemde word ook deur SGW voorgestel. Dit blyk egter dat die meerderheid Suid-Afrikaners wat die woord gebruik, verkies om dit uit te spreek: "gutta-perka".

In die soeke na Afrikaanse woorde of terme is dit belangrik om te onthou dat ' $n$ lomp of lang woord of term die stryd teen sy Engelse eweknie en sy verafrikaanste vorm gaan verloor, mits die woord (term) nie "kort en kragtig" is nie. Kollegas en ander belangstellendes kan gerus probleemwoorde aanteken en aanstuur. Moontlike nuwe skeppings sal ook verwelkom word. Die Afrikaanse tandheelkundige vaktaal het die hulp van al sy gebruikers nodig om dit tot almal se bevrediging te verryk en uit te bou.

\section{LITERATUURVERWYSINGS}

1. Brink, A.J. (1979). Woordeboek van Afrikaanse Geneeskundeterme (Nasou Bpk., Goodwood).

2. Snyman, H.W. (1988). Geneeskundewoordeboek (Butterworth, Durban).

3. Sykes, J.B. (1979). The Concise Oxford Dictionary of current English (Oxford University Press, Oxford). 